\title{
Christopher Kobrak (1950-2017): Subjects, Sources, and Serendipity
}

$S^{a}$ adly, Christopher Kobrak passed away a few days before his sixtyseventh birthday. He was a trustee of many of our business history associations and a personal friend. He was a larger-than-life presence at most of the major business history conferences, with his booming voice easily heard above the din of the general conversation. Speaking with Christopher McKenna of the Saïd Business School at Oxford University, he and I both realized we had lost one of our consummate academic-social networkers for the field, a person who brought together people on both sides of the Atlantic for vigorous discussions over dinners, in meetings, at workshops, and over glasses of wine. Planning to work with Chris on yet another collaboration in January, I had spent the 2017 New Year's Eve with him. He was in excellent spirits. As usual, he was talkative, engaged, energetic, and combative in his entertaining way; he was debating with his guests, glass of wine in hand, and enjoying being back in what was probably his favorite place in the world-his apartment in the lively eleventh arrondissement of Paris.

Although academia, and writing in general, can be a lonely endeavor, Chris managed to make writing social and collaborative. Indeed, much of his academic work was written in partnership-with Mira Wilkins, Andrea Schneider, Jana Wuestenhagen, Per Hansen, Rowena Olegario, Joe Martin, Donald Brean, Janette Rutterford, Michael Troege, and me, among others. Although Chris lived and traveled around the world, he made sure that he had cheap international calling because that kept him connected. Whether through his dinner parties, his invitations to spontaneous lunches or drinks, the open door to his office, or his hosting of nearly a hundred people at his home for the European Business History Association conference in Paris in 2012, Chris was about connecting people through socializing. We met for the first time at a conference in Bratislava and immediately began discussing the differences between German and American business cultures (now called "varieties of capitalism"). This initial debate eventually resulted in a series of jointly written articles for this journal. We were to work on a third 
about the cultural-political dimensions of the 1873 crisis in the United States and Germany. ${ }^{1}$

I like to think there was something of the Old World about him in creating a sort of modern-day intellectual salon. For Chris, this was less "networking" than a way of creating an extended intellectual family, as a way of life, and not just as some sort of instrumental connection as implied by the term. Ideas were something to pore over, discuss, bounce off of someone else; they were something to figure out, developing nuances, or honing further in conversation among friends or potential friends in a social circle. Ideas were social, not sterile things written on a page. People sensed this in Chris and were drawn to him.

A number of personal remembrances are posted on various business history association websites, but here I would like to focus briefly on Chris's academic contribution to business history and to elucidate his intellectual ideals. ${ }^{2}$ To quote Chris: "The more I pursue business and financial history, the more I become persuaded of serendipity's role not only in one's personal and professional life but also in what one learns about the past... The more I study history, the more too I realize it is about sources as much as about subjects." 3 Through his research, Chris not only became increasingly sensitive to the importance of sources, but about the serendipitous, fragmentary nature of archives and what they could really tell us about the past.

An academic colleague once stated that historians are drawn to subjects that somehow illuminate themselves in their work. The most straightforward implication was that people become interested in historical themes that affect them personally, or affected their family. This generalization certainly applied to Chris. For him, the "serendipity" of being born in New York City to a Jewish emigré father is most obvious. His father, Helmut, who had escaped Nazi Germany in the 1930s, managed to impart to Chris a lifelong "love of Berlin and German

\footnotetext{
${ }^{1}$ Jeffrey Fear and Christopher Kobrak, "Banks on Board: German and American Corporate Governance, 1870-1914," Business History Review 84, no. 4 (2010): 703-36; Jeffrey Fear and Christopher Kobrak, "Diverging Paths: Accounting for Corporate Governance in America and Germany," Business History Review 80, no. 1 (2006): 1-48.

${ }^{2}$ See Andrea Schneider, "In Memoriam Christopher Kobrak," European Business History Association website, n.d., http://www.ebha.org/files/news/InmemoriamChristopherKobrak. pdf; Andrew Smith, "Reflections on the Death of Christopher Kobrak," The Past Speaks (blog), 10 Jan. 2017, https://pastspeaks.com/2017/01/10/reflections-on-the-death-ofchristopher-kobrak/; ESCP Europe Finance Department (where he worked for the bulk of his academic career), "In Memoriam Professor Christopher Kobrak," ESCP Europe website, 26 Jan. 2017, http://www.escpeurope.eu/nc/media-news/news-newsletter/news-single/article/ in-memoriam-professor-christopher-kobrak/; and Jeffrey Fear, "Christopher Kobrak, In Memoriam (January 21, 1950-January 8, 2017)," Association of Business Historians website, n.d., http://www.abh-net.org/Christopher\%20Kobrak\%201950-2017.pdf.

${ }^{3}$ Christopher Kobrak, Banking on Global Markets: Deutsche Bank and the United States, 1870 to the Present (Cambridge, U.K., 2008), xiii-xiv.
} 
history" in spite of his own horrible experience of flight and exile. ${ }^{4}$ Chris's lifelong interest in the relationship of business to Nazism, and business ethics more generally, owes much to his father and this fascination with business complicity in the crimes of the Third Reich. He was also proud that one member on his family tree reached back to Eduard Lasker, the Jewish liberal who blew the whistle on the many scandals following the 1873 financial crash in Germany. Chris used to say that his own interest in business, corporate governance, and financial crashes had family roots. History was personal.

Chris was also drawn to themes of emigration: how executives and businesses managed across borders, how they managed risk, and how people lived transatlantic lives-very much like Chris himself. For the German-American Immigrant Entrepreneurship project through the German Historical Institute in Washington, D.C., Chris produced three short biographies: of Julius Weltzien, a Berlin-born, half-Jewish executive of Schering AG who managed its American subsidiary in the $1920 \mathrm{~s}$ and emigrated only semi-successfully to the United States in 1938; of Henry Villard, a Rhenisch-born financier of the Deutsche Bank who helped manage the American Northern Pacific railroad and the electrification of the Pacific Northwest; and of Otto Jeidels, one of the leading German-Jewish bankers of the interwar period, who emigrated to the United States and briefly held positions at Lazard Frères and Bank of America in San Francisco. ${ }^{5}$ All of these biographies were drawn from Chris's two extended research projects on Schering AG and the Deutsche Bank in America. ${ }^{6}$ He was drawn to these emigré stories, as they told of these men's departure to another country, often in traumatic circumstances, or of how they adopted some aspects of the new culture while injecting values or patterns of the old. For Weltzien and Jeidels, however, their American careers faded or were tragically cut short. Crossing borders was not just a challenge and an opportunity for renewal, but also potentially a personal and professional risk for

\footnotetext{
${ }^{4}$ Christopher Kobrak, National Cultures and International Competition: The Experience of Schering AG 1851-1950 (Cambridge, U.K., 2002), dedication.

${ }^{5}$ Christopher Kobrak, "Julius Weltzien and the Interwar Transatlantic Business Dilemma: Nationalism and Internationalism Corrupted," in Immigrant Entrepreneurship: GermanAmerican Business Biographies, 1720 to the Present (hereafter, IE), vol. 4, ed. Jeffrey Fear, German Historical Institute (hereafter GHI), last modified 25 Sept. 2014, http://www. immigrantentrepreneurship.org/entry.php?rec $=131$; Christopher Kobrak. "A Reputation for Cross-Cultural Business: Henry Villard and German Investment in the United States," in $I E$, vol. 2, ed. William J. Hausman, GHI, last modified 30 Sept. 2015, http://www.immigrant entrepreneurship.org/entry.php?rec=26; Martin Münzel and Christopher Kobrak, "Otto Jeidels: Cosmopolitan 'Realist,"' in $I E$, vol. 4, ed. Jeffrey Fear, GHI, last modified 6 Feb. 2014, http://www.immigrantentrepreneurship.org/entry.php?rec=60.

${ }^{6}$ Kobrak, National Cultures and International Competition; and Kobrak, Banking on Global Markets.
} 
decline or isolation. Chris too underwent this cross-border, cross-cultural risk-although successfully. Though Chris was born in New York, he also made a home in Europe; he became emotionally rooted in Paris, but yet again in the final years of his life, he joined the Rotman School of Management in Toronto, Canada. He was a true cosmopolitan, yet still kept his emotional roots in New York and Paris.

Chris was a poster child for why people should not retire at a mandatory age. In Toronto, he all too briefly inhabited the L. R. Wilson/ R. J. Currie Chair in Canadian Business and Financial History at Rotman School of Management. In 2015 he initiated the establishment of the Canadian Business History Association (CBHA), modeled after the Gesellschaft für Unternehmensgeschichte (GuG or Society for German Business History). GuG seeks to establish close contacts with businesses, to advise them on creating archives for the future, and to cooperate with them to tell their stories in a professional and accurate but critical, non-hagiographic manner. Above all, for Chris, the CBHA was a means of creating the archival sources for future historians.

One of the first conferences held by the newfound CBHA in May 2016 reflected one of Chris's primary interests: the ethical "place," "legitimacy," and "reputation" of business in society, a theme he became ever more engaged with since the 2007-2008 financial crisis.7 The CBHA is a prime example of cross-national cross-fertilization of ideas pollinated by Chris himself as a sort of human bumblebee of our profession-in this case transferring ideas from Germany to Canada by way of France and America.

In terms of subject matter, Chris's work focused most on international business and finance, issues surrounding foreign (portfolio and direct) investment, banking-financial-insurance history, the impact of business and financial regulation, corporate governance issues, and political risk. At the end of his life, he became increasingly animated in the epistemology and research methodologies of (business) history itself. He was passionate when discussing appropriate research methods and questions; he loved asking complex questions and could argue for hours on the possibilities of history. He was an ardent defender of the importance of history to management studies. However, he made a sharp distinction between what he considered good (business) history and the use of history to elucidate theory-that is, not-so-good (business) history, or "the growing tendency to integrate business history into business studies by producing business theory and by organizing the field as

\footnotetext{
${ }^{7}$ Christopher Kobrak, "The Concept of Reputation in Business History," Business History Review 87, no. 4 (2013): 763-86; Christopher Kobrak and Mira Wilkins, eds., History and Financial Crisis: Lessons from the 2oth Century (London, 2013).
} 
case material for business study." 8 Although he spent most of his professional academic life in finance departments of management schools, Chris constantly asserted the importance of history and the historical approach-placing the particular into a broader historical context in an accurate, accessible manner based on primary sources. Accessibility and accuracy properly situated in context, not the theory, he asserted, would be of most use to practitioners and other academics whatever the discipline. That was historians' comparative advantage that should not be lost or given away lightly.

For Chris, the story of business-of history in general-had to be based primarily on archival sources, based on scholarly standards of the historical discipline (not other disciplines, however useful their borrowings may be) and written in an accessible way. He criticized Alfred D. Chandler Jr. for having "left much of the social and political dimension of business to journalists and non-professional historians" in the interest of developing an economic theory of management strategies and structures, of scale and scope. He criticized journalists who tended to latch on to only the more sordid aspects of business-no matter how true-but without a broader understanding about the constraints or contexts under which business operated or how business has transformed society. ${ }^{9}$ He criticized political historians who focused on businessgovernment relations without understanding the economics of the industry, or of the dynamics of competition in a particular sector at a particular time, or the imperative of business to earn profits. He critiqued historians of technology who naturally focused on innovation and technical change, but less on how these altered society or how they were commercialized within a business. And he criticized economists for abstracting away real people, real business executives who ran their companies with a mixture of profit seeking (utter greed at times) and all-toohuman weaknesses and emotions. In terms of thematic foci, there was nothing inherently wrong with these approaches or with utilizing distinct methodologies except that in branching off into specific subject themes they lost sight of the context(s) of the firm as a whole in its broader

\footnotetext{
${ }^{8}$ Christopher Kobrak and Andrea Schneider, "Varieties of Business History: Subject and Methods for the Twenty-First Century," Business History 53, no. 3 (2011): 401-24. See R. Daniel Wadhwani and Marcelo Bucheli. eds., Organizations in Time: History, Theory, Methods (Oxford, 2014); Michael Rowlinson, John Hassard, and Stephanie Decker, "Research Strategies for Organizational History: A Dialogue between Historical Theory and Organization Theory," Academy of Management Review 39, no. 3 (2013): 250-74; Michael Rowlinson, "Management \& Organizational History: The Continuing Historic Turn," Management \& Organizational History 8, no. 4 (2013): 327-28; Paul C. Godfrey, John Hassard, Ellen S. O'Connor, Michael Rowlinson, and Martin Ruef, "What Is Organizational History? Toward a Creative Synthesis of History and Organization Studies," Academy of Management Review 41, no. 4 (2016): 590-608.

${ }^{9}$ Kobrak, National Cultures and International Competition, preface.
} 
complex and often contradictory environments. For Chris, by contrast, practicing business executives had to deal with the many dimensions of business simultaneously; thus, a historian should try to write business histories more holistically as well:

Business history has always been and always will be the story and explanation of firms' evolution in their political, social, technological, and economic contexts. Our idea of a good history not only needs rich sources but also poignant connections to contexts. It is how the sources and contexts are fused that differentiates our work from that of science (even the social sciences). Although we do not believe that a subject is defined by methodology, and we believe that methodology should neither be dogmatic nor uniform, nor an activity for itself-to the exclusion of real research-as scholars we owe it to our work and to our audiences to reflect from time to time on the standards of our discipline... Scholarship that integrates broad social and economic questions into historical narrative, based on solid historical sources, can help link rather than divide our discipline from the social sciences. ${ }^{10}$

For Chris, proper historical methodology was not about developing a new sort of theory, or even utilizing a particular theory to assess or test historical information, but about discussing how best to use primary source documents, the "proper role of financial analysis," the specific limits of commissioned histories, and the specifics of methods most appropriate for understanding business. He embedded business history within the general rules of scholarship as a professional historian, that is, situating the "methodology and the interpretation of evidence" in their proper historical context, not in proving existing theory or building new theories. This meant, above all, working with archival sources. In this respect, he was a true historian first and a finance professor second, although his main teaching field was finance. He located business history solidly within the historical method: "illuminating particular events, institutions, and individuals, a mission that is enhanced by placing them in their historical contexts."11

To understand this approach, one has to understand his background, his mentors, and the historians he most admired: Fritz Stern, Volker Berghahn, Peter Hayes, Mira Wilkins, and especially Gerald Feldman. Having known him long enough, I can say that Chris was in many ways a displaced German historian who happened to study business. One of the unique aspects of working on business in the German history context is that the issue of business complicity in the crimes of

\footnotetext{
${ }^{10}$ Kobrak and Schneider, "Varieties of Business History," 406-7.

${ }^{11}$ Ibid., 409.
} 
the Third Reich plays an outstanding role for business historians, and so political history, business ethics, and business history are always entwined-and not primarily through "regulation," as in the American case. The Nazi period places particular demands on business historians.

Fritz Stern sparked Chris's interest in elegantly written, general German history, but in particular through an intellectual-political approach to history that made Jewish life and anti-Semitism central to understanding any story of Germany or German capitalism. Chris and Andrea Schneider's "varieties of business history" article selfconsciously referenced Stern's "varieties of history" on historiography. Chris was particularly impressed by Gold and Iron, about Gerson Bleichröder's relationship to Otto von Bismarck; Bleichröder was a leading Jewish banker and personal banker to Bismarck, which symbolized the symbiotic relationship of Jews and Germans in German history before Hitler tore it irrevocably apart. ${ }^{12}$

From Volker Berghahn, Chris drew inspiration from his ability to link business history to general history-viewing it not as a separate subfield but as integral to understanding modern history. He and Berghahn overlapped considerably in their research interests, in particular, transatlantic German-American relations in the twentieth century. ${ }^{13}$ With his family and his own life, Chris embodied this complicated, and often torturous, interweaving of German and American life fates. Chris's two main books focus on German-American business connections. His first book, on Schering AG (based on his dissertation "National Cultures and International Competition: The Experience of Schering AG 18511950") had as one of its main focuses German foreign direct investment in America. His second book, on the Deutsche Bank, Banking on Global Markets: Deutsche Bank and the United States 1870 to the Present, dealt with German banking relations with the United States. Together, he and I wrote a number of comparative articles on German and American accounting practices and corporate governance reforms,

\footnotetext{
${ }^{12}$ The following are classics by Fritz Stern: Varieties of History: From Voltaire to the Present (New York, 1956); The Politics of Cultural Despair: A Study in the Rise of the Germanic Ideology (Berkeley, 1961); Gold and Iron: Bismarck, Bleichröder, and the Building of the German Empire (New York, 1977); "Capitalism and the Cultural Historian," in Dreams and Delusions: National Socialism in the Drama of the German Past (New York, 1989), 274-90; and Five Germanies I Have Known (New York, 2006).

${ }^{13}$ See the following by Volker R. Berghahn: The Americanization of West German Industry, 1945-1973 (Oxford, 1986); (as editor) Quest for Economic Empire (New York, 1996); Europe in the Era of Two World Wars: From Militarism and Genocide to Civil Society, 1900-1950 (Princeton, 2006); Industriegesellschaft und Kulturtransfer (Göttingen, 2010); Umbau im Wiederaufbau: Amerika und die deutsche Industrie im 20. Jahrhundert (Jena, Germany, 2013); American Big Business in Britain and Germany: A Comparative History of Two "Special Relationships" in the 2oth Century (Princeton, 2014).
} 
which hopefully contributed to understanding how "varieties of capitalism" emerged over time.

From Peter Hayes, one of the world's leading Holocaust scholars, Chris drew lessons on the profound ways in which business profit seeking could all too easily become complicit in the crimes of the Third Reich. ${ }^{14} \mathrm{He}$ found it particularly fascinating, significant, and horribly disheartening how other members of the same business could purge Jews with whom they had worked side-by-side for years-many they had called friends. Although Chris defended the role and importance of business in society and was an advocate of "light touch" regulation in general, this position grew in good part out of his conviction that no amount of regulation or legal prescriptions could replace basic human decency, good judgment, and ethical, reputable behavior on the part of committed and responsible capitalists or executives themselves. At the end of our two joint articles, we stressed the continuing dangers of arms-length shareholding through chains of intermediary agents such as pension funds, investment banks, and money managers, which are ostensibly working in the fiduciary interests of shareholders. The amount of information needed to monitor these agents over time and space has grown voluminously, yet has still not overcome these evergrowing distances: "Paradoxically, while most of this information is designed to reduce informational asymmetries and agency costs-that is, to build trust-it has resulted in a considerable increase in information, accounting, and transaction costs that now constitute a large burden to firms in terms of time and money." 15

Since the meltdown of Lehman Brothers, the most recent financial crisis exposed deep deficiencies of global capital markets that even the most detailed regulations and ostensible transparency failed to overcome. The utter failure of the financial system and business ethics animated Chris's unfinished work, which should be forthcoming. His move to Canada inspired comparisons with a financial system much more stable than that of the United States. ${ }^{16}$ Chris felt that more

\footnotetext{
${ }^{14}$ See the following by Peter Hayes: Industry and Ideology: IG Farben in the Nazi Era (New York, 1987 and 2001); "History in an Off Key: David Abraham's Second Collapse," Business History Review 61, no. 3 (1987): 452-72; From Cooperation to Complicity: Degussa in the Third Reich (Cambridge, U.K., 2007); and, with John K. Roth (eds.), The Oxford Handbook of Holocaust Studies (Oxford, 2010).

${ }^{15}$ Quote from Fear and Kobrak, "Diverging Paths," 48; see also Fear and Kobrak, "Banks on Board," 736.

${ }^{16}$ Kobrak, "The Concept of Reputation"; Christopher Kobrak and Michael Troege, "From Basel to Bailouts: Forty Years of International Attempts to Bolster Bank Safety," Financial History Review 22, no. 2 (2015): 133-56; Christopher Kobrak, "Interwar Financial Meetings and Global Summitry," Global Summitry Journal (forthcoming); Christopher Kobrak and Donald Brean, eds., "History and Finance" (proposed volume for University of Toronto Press [forthcoming]); Christopher Kobrak, Joe Martin, and Darren Karn, "Canadian
} 
historical perspective was needed to inform ethical behavior of business executives and contribute to business education. Businesspeople needed to want to behave ethically; no amount of legislation could stop unethical behavior on the part of individuals if they wanted to circumvent them. And this behavior would undermine their own businesses and profits in the long run. During the Third Reich, businesses followed shortterm profits (or expectation of profits), but ended up destroying their businesses and the society around them. Businesses' relationship to the Nazi regime was an extreme point of reference for the evil that business executives could inflict upon their fellow human beings and their surrounding social world by demonizing other groups, or burrowing behind the following of orders, or seeking narrow profits at the expense of others.

Mira Wilkins was not just a mentor, but one of Chris's closest collaborators. ${ }^{17}$ Chris was always inspired by her deep knowledge of international business. His specific works on individual firms, Schering AG and the Deutsche Bank, were informed by her works on foreign direct investment and her appreciation of just how difficult doing business could be once firms crossed borders. For example, the Deutsche Bank established Germany's first auditing firm in the United States, the Deutsch-Amerikanische Treuhand-Gesellschaft (later the Deutsche Treuhand Gesellschaft that eventually merged into a global KPMG in the 1980 ) to monitor and manage the risk of its overseas American investments, especially its financially problematic railroads such as the Northern Pacific. The political risks faced by business when moving abroad was a core interest. ${ }^{18}$ Chris and Wilkins most recently worked together for a 2011 special issue of Business History on the "2008 crisis" within a broad historical perspective about financial crises. ${ }^{19}$ In it, they plead for

Banking in the 1980 s and the Creation of OSFI" (unpublished paper [forthcoming]); Christopher Kobrak with Jeffrey Fear, "Making Capitalism Respectable: Conflicting Sonderwegs and the Origins of German and American Corporate Governance" (unpublished paper [forthcoming]).

${ }^{17}$ See the following by Mira Wilkins: The Emergence of Multinational Enterprise: American Business Abroad from the Colonial Era to 1914 (Cambridge, Mass., 1970); The Maturing of Multinational Enterprise: American Business Abroad from 1914 to 1970 (Cambridge, Mass., 1974); The History of Foreign Investment in the United States to 1914 (Cambridge, Mass., 1989); The History of Foreign Investment in the United States, 1914-1945 (Cambridge, Mass., 2004); with William Hausman and Peter Hertner, eds., Global Electrification: Multinational Enterprise and International Finance in the History of Light and Power, 1878-2007 (Cambridge, U.K., 2008); and American Business Abroad: Ford on Six Continents, 2nd ed. (Cambridge, U.K., 2011).

${ }^{18}$ Fear and Kobrak, "Banks on Board," 718-19; Fear and Kobrak, "Diverging Paths," 11-12; Christopher Kobrak and Per H. Hansen, eds., European Business, Dictatorship, and Political Risk, 1920-1945 (New York, 2004).

${ }^{19}$ Christopher Kobrak and Mira Wilkins, "The '2008 Crisis' in an Economic History Perspective: Looking at the Twentieth Century," Business History 53, no. 2 (2011): 175-92, reprinted in Kobrak and Wilkins, History and Financial Crisis. 
more historical perspective and to recognize the "methodological tension" (as expressed by Charles Kindleberger) that "History is particular; economics is general": "good economic history integrates the general with the particular, showing how historians might address broad economic questions and exposing economists to the complex historical data necessary for good theory." History was less about building better theory, and more about developing better "wisdom" and perspective. ${ }^{20}$

Finally, the late Gerald Feldman was probably the historian and person Chris most admired-and the one who most informed his scholarship and approach. Feldman wrote about German political economy and business with a serious but humorous flair and always insisted on the strongest possible archival-empirical basis for any good history. ${ }^{21}$ Chris's defense of the historical method, of the use and abuse of history for understanding business or financial crises, of uncovering the true virtues and crimes of business, owed a great deal to Feldman. They became very close friends; they had a similar sense of humor combined with a seriousness about sources and scholarship. For both of them, there was no way to understand German history, particularly the horrible evil course that Germany took in the early twentieth century, without understanding business. Business was an active participant in creating Nazi Germany-including how it helped to undermine Weimar democracy, how it participated in Jews" "social death" through ostracism, robbing them of their property, and how it then helped build the weapons of war and build concentration camps or insure them. Both Chris and Feldman advocated a critical history of business, but one that should hate and assign blame precisely based on the historical record. One historian called this approach to history "critical empiricism." Uncovering the past would not lead to some sort of objectivity as if it were an Archimedean point above history itself, but provide a field of debate for "mutually intelligible discussion and the effort to persuade and possibility of being persuaded on the basis of shared methods and standards." ${ }^{22}$ Interpretation and analysis needed debate, grounded in

\footnotetext{
${ }^{20}$ Kobrak and Wilkins, “The '2008 Crisis' in an Economic History Perspective,” in History and Financial Crisis, 5 .

${ }^{21}$ See the following by Gerald D. Feldman: Army, Industry, and Labor in Germany, 19141918 (1966; repr. Oxford, 1992); Iron and Steel in the German Inflation, 1916-1923 (Princeton, 1977); The Great Disorder: Politics, Economics, and Society in the German Inflation, 1914-1924 (Oxford, 1993); with Lothar Gall, Harold James, Carl-Ludwig Holtfrerich, and Hans E. Büschgen, A History of the Deutsche Bank, 1870-1995 (Munich, 1995); Allianz and the German Insurance Business, 1933-1945 (Cambridge, U.K., 2001).

${ }^{22}$ Feldman, Great Disorder, 10; Jeffrey Fear, "Gerald D. Feldman: An Appreciation," in History of Financial Institutions: Essays on the History of European Finance, 180o-1950, ed. Carmen Hofmann and Martin L. Müller (London, 2017), 1-12.
} 
sources and tested through argument. For Chris, this testing was as much academic as social.

Chris thought that more business schools should require history in their curriculum, mostly for the wisdom, perspective, and judgment that it might impart-not as case studies or empirical material to build theory. His own work on business ethics, big business and Nazism, and corporate fraud were clearly informed by some of the damage done by business in the twentieth century that affected his own family. And Chris always argued for greater academic-business collaboration to enhance access to information and archives: "The crux of our argument has been that some of the issues that divide business historians may be resolved by rededicating ourselves to integrating the general with the particular, and by improving our working relationship with the business community, which still controls many of the sources we need and our access to reliable indications of the particular." ${ }^{23}$ For Chris, history was a craft based on experience, judgment, and deep knowledge of context to render the particular more broadly significant. But it needed the particular, the sources, first. And those were fragmentary, hidden, forgotten, or buried-subject to the past's serendipity. The founding of the Canadian Business History Association by an American who primarily studied German history and lived in Paris while working as a finance professor is the ultimate expression of the confluence of influences and his intellectual ideals.

Jeffrey Fear, University of Glasgow

${ }^{23}$ Kobrak and Schneider, "Varieties of Business History," 417. 